Огляди літератури, оригінальні дослідження, погляд на проблему

УДК 615.371-084-053.4+616-051+616.915+616.916

DOI 10.11603/1811-2471.2016.v0.i4.7091

\title{
ОБҐРУНТУВАННЯ ШЛЯХІВ ПОДОЛАННЯ ДИТЯЧИХ ВІРУСНИХ ІНФЕКЦІЙ В УКРАЇНІ
}

\author{
○І. О. Федяк', І. І. Іванюлик', Г. Б. Матейко1, Т. В. Томашівська², Л. М. Бровінська", \\ Т. М. Камінська ${ }^{4}$, Г. С. Рожнова ${ }^{5}$ \\ Івано-Франківський національний медичний університет ${ }^{1}$ \\ Тернопільська міська дитяча комунальна лікарня ${ }^{2}$ \\ К3 «Вінницька обласна клінічна дитяча інфекційна лікарня» ${ }^{3}$ \\ Київська міська дитяча клінічна інфекційна лікарня ${ }^{4}$ \\ КЗОЗ «Харківська обласна дитяча інфекційна клінічна лікарня»
}

\begin{abstract}
РЕЗЮМЕ. У статті представлено результати проведеного анкетування лікарів (дитячих інфекціоністів та педіатрів) щодо питань протидії розповсюдженню в Україні вакцинокерованих дитячих вірусних інфекцій. Спеціалістами окреслено основні іміджеві та фінансові проблеми процесу вакцинації, надана оцінка поточного стану його фармацевтичного забезпечення і запропоновано варіанти подолання цих хвороб. Так, на думку лікарів, значне їх поширення в Україні, окрім власне відсутності вакцин, зумовлене відмовою батьків від вакцинації (40\%) та формуванням 3МІ негативної думки щодо користі імунопрофілактики (35\%). Потребує підняття самооцінка ролі лікаря у схилянні батьків на користь щеплень, а роль провізорів - гарантоване забезпечення якості та наявності вакцин. Залишається проблемою доступність та своєчасність доказової інформації щодо питань профілактики, лікування та протидії розповсюдженню дитячих вірусних інфекцій, оскільки 58 \% спеціалістів вважають, що їхня потреба в інформації задоволена частково.

КЛЮчОВІ СЛОВА: дитячі вірусні інфекції, вакцинація, анкетування
\end{abstract}

Вступ. За даними Всесвітньої організації охорони здоров'я (ВООЗ), у 2017 р. в Україні знову слід очікувати епідемію кору. Причина-низький рівень вакцинації [6]. Загалом, як повідомляється на сайті представництва ООН в Україні, наша держава має найнижчий рівень планової вакцинації у світі: станом на серпень 2016 р. тільки 30 \% дітей в Україні повністю вакциновані від кору [2]. Тому у 2016 р. зафіксовано зростання захворюваності на цю дитячу вірусну інфекцію (ДВІ) в Івано-Франківській, Одеській, Київській, Львівській та Чернівецькій областях. Так, в Івано-Франківській області за останні 3 місяці 2016 р. зареєстровано 56 випадків захворювання на кір (а в попередні роки реєструвалися лише поодинокі випадки). Серед тих, хто захворів, переважають діти до 15 років, що становить $69,6 \%$, із них 35,8 \% дітей - не вакциновані [1].

Ще у 2012 р. в Україні працювала місія експертів ВООЗ, ЮНІСЕФ, Європейського та Американського центрів з боротьби з інфекційними захворюваннями, яка провела оцінку системи управління програмою імунізації. Експерти місії відзначили несвоєчасне та нерівномірне забезпечення лікувально-профілактичних закладів (лПЗ) імунобіологічними препаратами, включеними до календаря профілактичних щеплень; збільшення числа медичних протипоказань, відмов від профілактичних щеплень. Тому залишається висока ймовірність подальшої передачі інфекцій чи спалахів хвороб, яким можна запобігти за допомогою вакцинопрофілактики $[3,5,8]$.

Окрім перебоїв з постачанням вакцин, що були упродовж останніх років [7], мали місце й суб'єктивні причини критично низького рівня охоплення імунізацією в Україні.

Метою даної роботи було дослідження цих причин, а також опрацювання стратегії подолання вакцинокерованих ДВІ (кору, краснухи) шляхом вивчення думок експертів - вітчизняних лікарів.

Матеріал і методи дослідження. У процесі дослідження використовували методи інформаційного пошуку, опитування шляхом анонімного анкетування дитячих інфекціоністів, педіатрів різних регіонів України, узагальнення даних. Нами розроблено опитувальну анкету, в якій спеціалістам в області ДВІ було запропоновано дати оцінку поточного стану вірусних вакцинокерованих інфекцій та окреслити шляхи їх подолання в Україні. Проведено анкетування 60 лікарів з різним стажем роботи за спеціальністю та кваліфікаційною категорією. Опитування проводили у відділеннях дитячих інфекційних лікарень міст Києва, Вінниці, Харкова, Тернополя та Івано-Франківська.

Результати й обговорення. Серед 60 лікарів дитячих інфекціоністів було $60 \%$, педіатрів - $40 \%$. За стажем роботи переважали фахівці, які працювали за спеціальністю 20-30 років (28\%), практично порівну було лікарів зі стажем до 5 років (22 \%), 5-10 років (20\%), 10-20 років (20\%), найменше понад 30 років (10\%). За кваліфікаційною категорією переважали спеціалісти з вищою і першою (35\% та $25 \%$ відповідно), без категорії - $23 \%$, 3 другою - $17 \%$. Серед лікарів було по 2 \% зі званням доцента та Заслуженого лікаря; завідувачі відділень становили $20 \%$, решта - практичні працівники (80\%). Отже, вибірку респондентів можна 
Огляди літератури, оригінальні дослідження, погляд на проблему

вважати достатньо кваліфікованою та репрезентативною щодо різних категорій спеціалістів.

В інформаційній частині анкети лікарям було запропоновано дати відповідь на 10 тестових запитань, які включали можливість написання свого варіанту відповіді, та 1 відкритого питання, яке стосувалося інформаційного забезпечення процесу фармакотерапії дітей, хворих на ДВІ (рис. 1-9).

Отже, лише 37 \% лікарів вважають, що вони володіють повною інформацією про новітні дока- зові підходи до профілактики та лікування хворих на ДВІ. Однак лише $27 \%$ фахівців конкретизували, яка додаткова інформація про ЛП їх цікавить: $15 \%$ - щодо застосування ЛП у світовій практиці, 7 \% - щодо доведеної ефективності, 3 \% - побічної дії, 2 \% - ціни та наявності лП в аптеці.

Отже, як свідчить аналіз відповідей респондентів на 1 тестове запитання, який графічно представлений на рисунку 2, серед лікарів переважає твердження, що значне поширення в Укра-

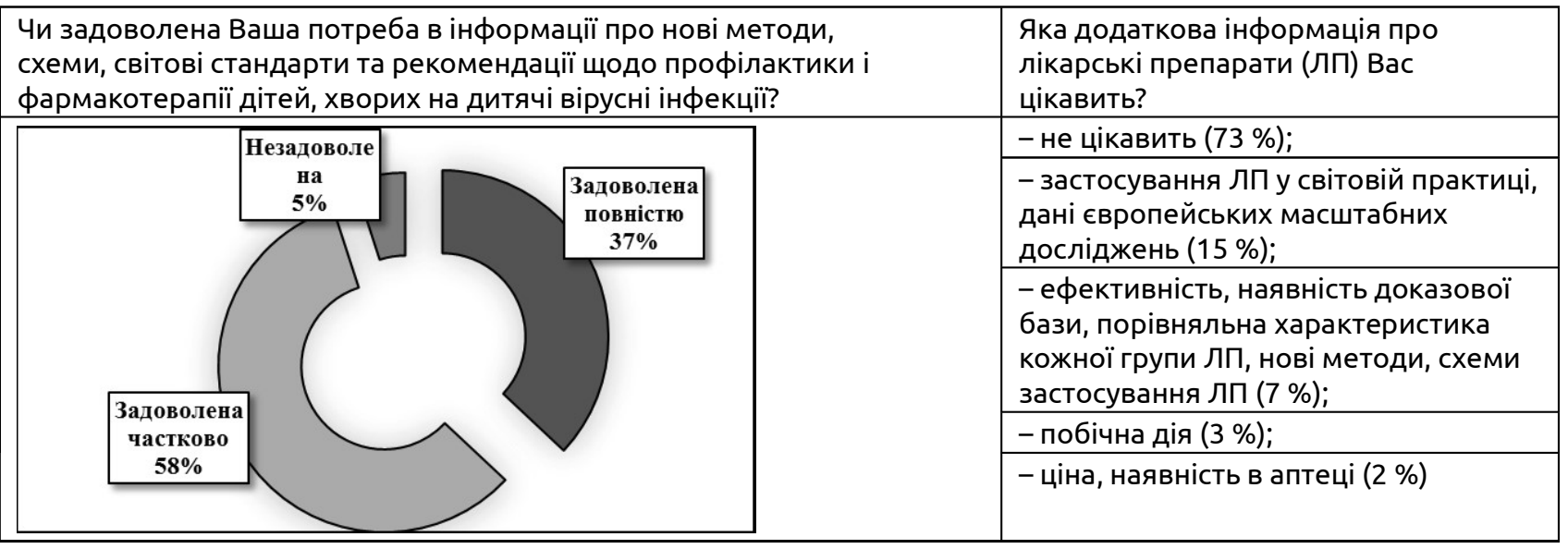

Рис. 1. Розподіл відповідей лікарів щодо повноти наявної фахової інформації.

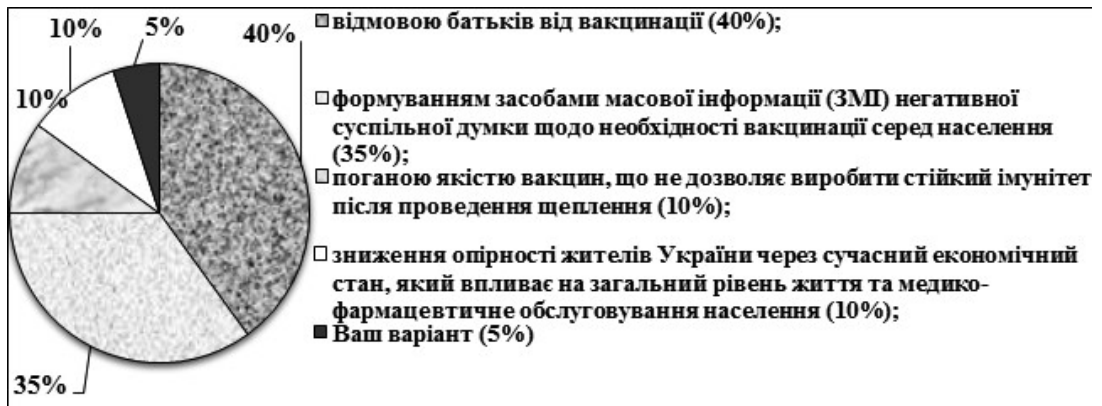

Ваш варіант: відсутність вакцин; високий рівень міграції населення; безвідповідальне ставлення до висловлювань своїх думок медичними працівниками; відсутність єдиної державної політики щодо вакцинації.

Рис. 2. Розподіл відповідей лікарів на запитання: "Вкажіть, чим пояснюється, на Вашу думку, значне поширення в Україні в останні роки кору, краснухи, вітряної віспи як серед дітей, так і серед дорослих?»

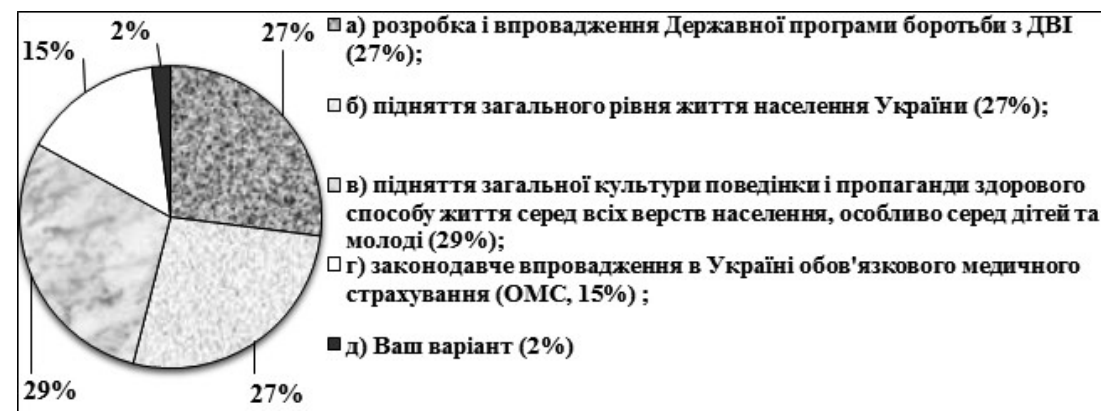

Ваш варіант: вакцинація; впровадження концепції відповідальності пацієнта.

Рис. 3. Розподіл відповідей лікарів на запитання: «Вкажіть можливі шляхи запобігання в Україні росту захворювань на ДВІ в сучасних умовах?» 
Огляди літератури, оригінальні дослідження, погляд на проблему

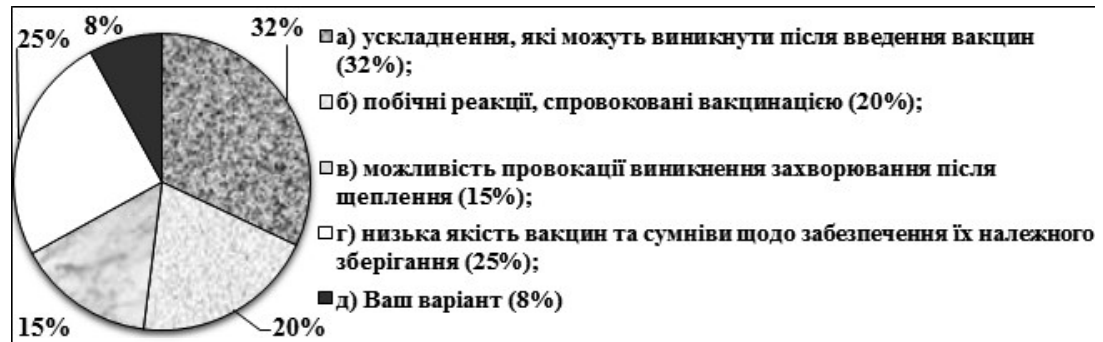

Ваш варіант: пропаганда в соціальних мережах і на телебаченні; відсутня сучасна медична допомога, все залишилося в соціалістичному суспільстві

Рис. 4. Розподіл відповідей лікарів на запитання: «Вкажіть можливі причини відмови від вакцинації в Україні в останні роки?».

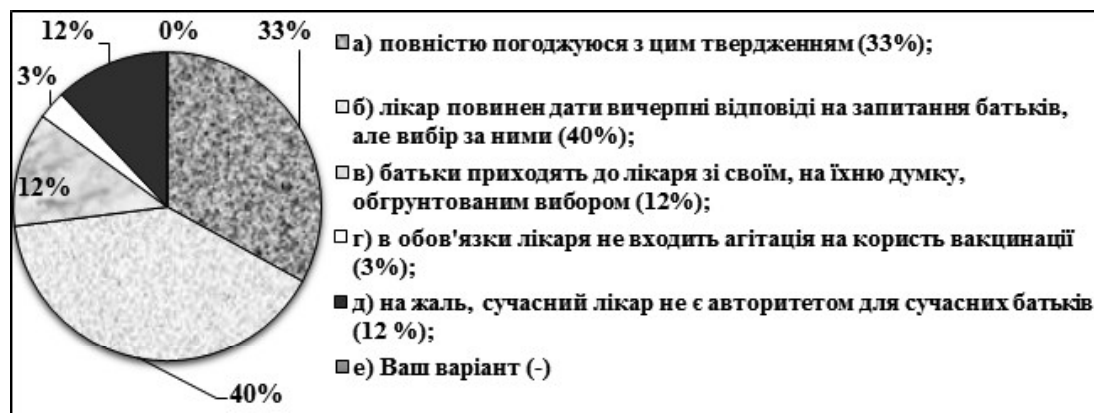

Рис. 5. Розподіл відповідей лікарів на запитання: «Чи підтримуєте Ви думку, що авторитет лікаря $\epsilon$ визначальним у схилянні батьків на користь вакцинації для зниження рівня захворюваності ДВІ в Україні?».

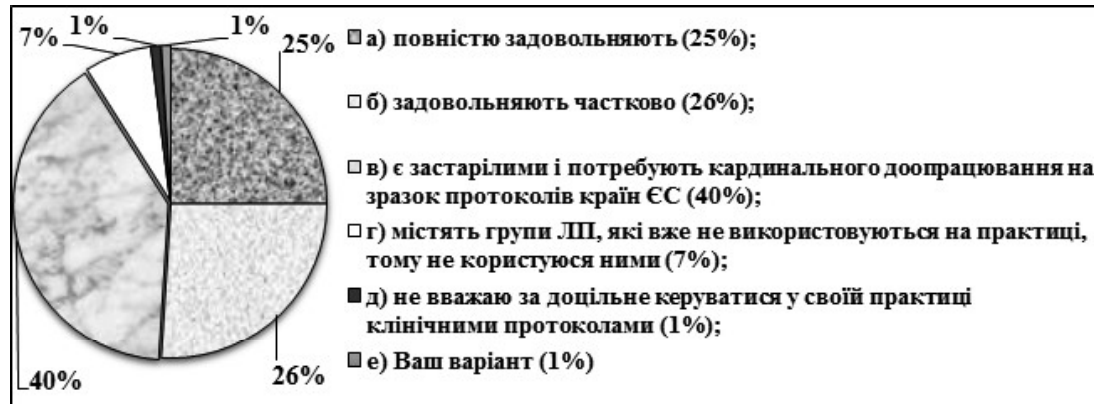

Ваш варіант: потреба у постійному оновленні

Рис. 6. Розподіл відповідей лікарів на запитання: «Вкажіть Ваше професійне ставлення до Клінічних протоколів діагностики та лікування інфекційних хвороб у дітей (Наказ МОз України № 354 від 09.07.2004 p.)» [4].

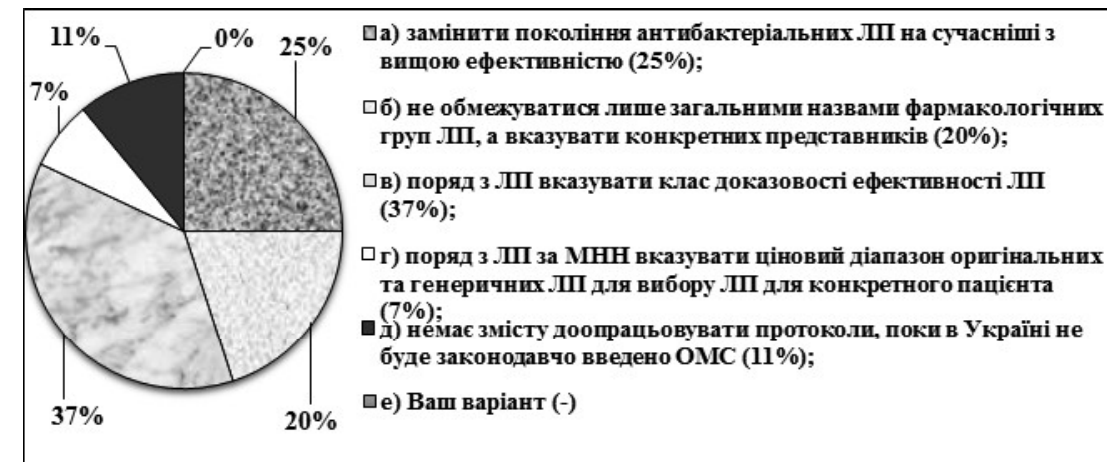

Рис. 7. Розподіл відповідей лікарів на запитання: «Якщо Ви вважаєте, що Клінічні протоколи діагностики та лікування інфекційних хвороб у дітей потребують доопрацювання, то виберіть, будь ласка, його характер». 


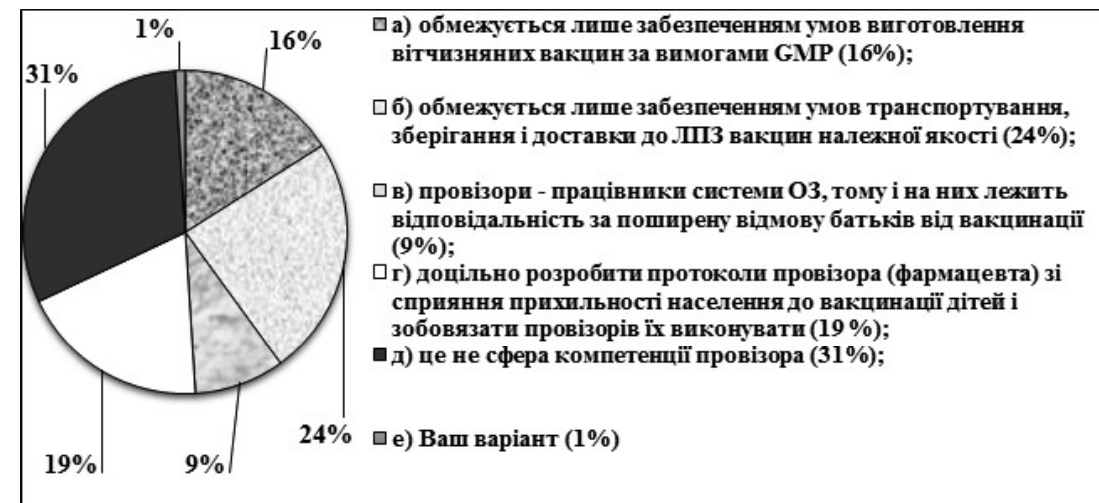

Ваш варіант: вироблення єдиної державної політики щодо вакцинації.

Рис. 8. Розподіл відповідей лікарів на пропозицію: «Окреслити роль провізорів у питаннях імунопрофілактики дитячого населення України».

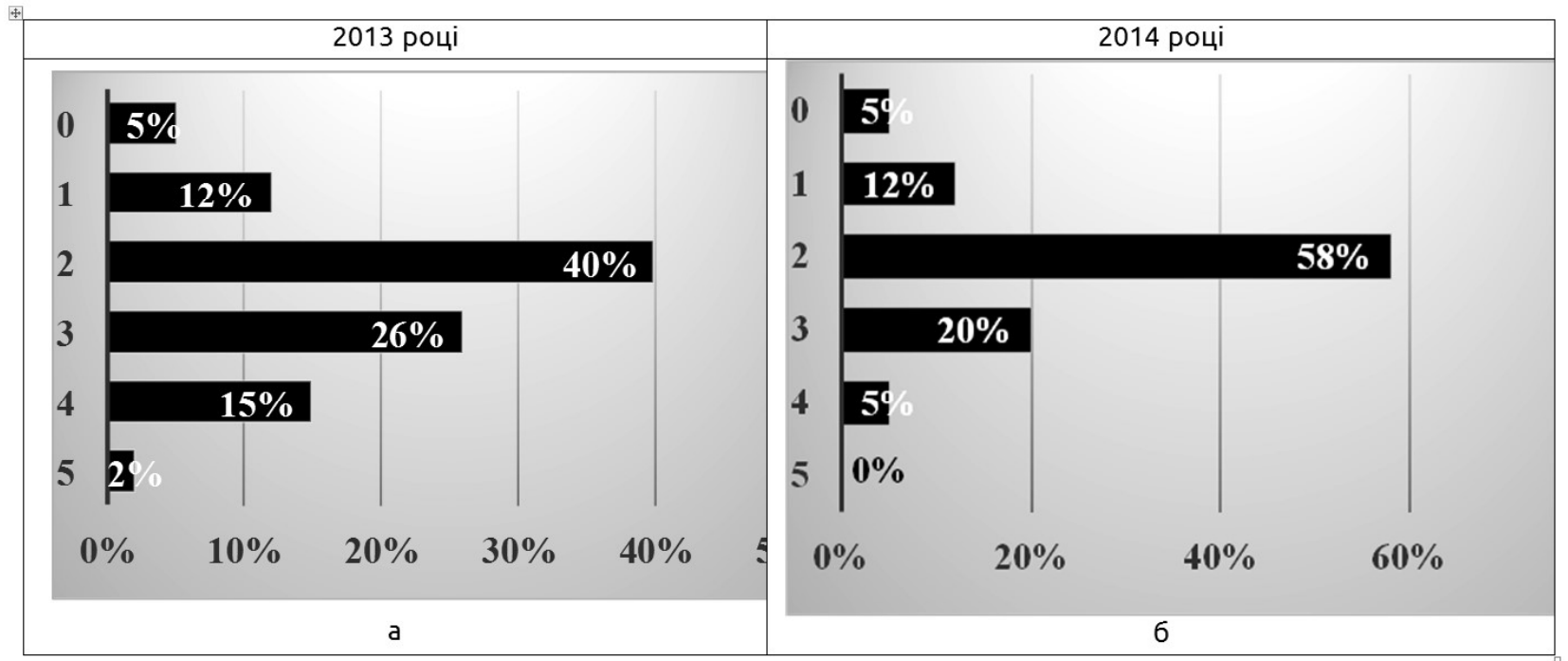

Рис. 9. Розподіл відповідей лікарів на пропозицію: «Просимо Вас оцінити за 5-бальною шкалою стан забезпечення вакцинами у 2013 р. (a) та 2014 р. (б)»

їні ДВІ найперше зумовлене відмовою батьків від вакцинації (40\%). На другому місці - формування у ЗМІ негативної думки щодо користі імунопрофілактики (35 \%). Третє місце поділили між собою твердження щодо неякісних вакцин і знижений імунітет як наслідок загального низького рівня життя співгромадян (по $10 \%$ ).

Пропаганда здорового способу життя серед дітей та молоді, на переконання 29\% опитаних лікарів, - основний шлях запобігання в Україні росту ДВІ (рис. 3). По 27 \% лікарів вважають таким шляхом впровадження в Україні Державної програми боротьби з ДВІ та підняття загального рівня життя співгромадян. Компенсацію недостатнього фінансування за рахунок коштів майбутнього фонду ОМС, як шлях подолання ДВІ, обрали 15 \% респондентів. Серед власних думок лікарів заслуговує на увагу пропозиція щодо впровадження концепції відповідальності пацієнта.

Основною причиною відмови батьків від вакцинації їх дітей 52 \% лікарів вважають поствакци- нальні ускладнення та побічні реакції, $25 \%$ - низьку якість вакцин та сумніви у батьків щодо їх належного зберігання, 15 \% - можливість провокації виникнення захворювання після щеплення (рис. 4).

Як показує розподіл відповідей респондентів (рис. 5), більшість лікарів належним чином оцінюють свою роль у практичній імунопрофілактиці. Адже 40 \% опитаних вважає, що від повноти інформації щодо користі вакцинації, наданої лікарем, залежить позитивна згода батьків на ії проведення, хоча і поважають їх право вибору, а 33 \% - повністю підтримали твердження, що саме авторитет лікаря $\epsilon$ прерогативою у переконанні батьків. 3 іншого боку, 27 \% спеціалістів не вбачають своєї вагомої ролі у цьому питанні: 12 \% лікарів вважають, що батьки приходять до них зі своїми переконаннями, які не піддаються корекції, $12 \%$ - сучасний лікар не $\epsilon$ авторитетом для сучасних батьків (12 \%), а 3 \% - не вважають агітацію на користь вакцинації прямим обов'язком дільничного лікаря. 
3 іншого боку, лікарі на даний час не готові частину своїх обов'язків щодо санітарно-просвітньої роботи серед населення віддати іншій ланці фахівців системи охорони здоров'я - провізорам і фармацевтам (рис. 8). Адже 31 \% лікарів взагалі не вважають це сферою компетенції провізорів, а $40 \%$ - обмежили роль провізорів, виділивши їм нішу зберігання (24 \%) і виготовлення (16 \%) вакцин. Водночас $19 \%$ лікарів підтримали думку про доцільність впровадження протоколів провізора (фармацевта) зі сприяння прихильності населення до вакцинації дітей та $9 \%$ - про паритетну моральну відповідальність і провізорів за поширену відмову батьків у вакцинації дітей.

Ще однією компонентою системи подолання ДВІ в Україні заслужено можна вважати необхідність розробки нових Клінічних протоколів діагностики та лікування інфекційних хвороб у дітей, регламентовані наказом МОЗ України № 354 від 09.07.2004 р. (надалі Протоколи, рис. 6). Цю тезу підтримали більшість опитаних лікарів: 40 \% - вважають, що Протоколи $\epsilon$ застарілими і потребують кардинального доопрацювання, 26 \% - задовольняють частково, 7 \% - містять групи та окремі лП, які вже давно не використовуються на практиці. Водночас насторожує наявність аж $25 \%$ відповідей лікарів, яких повністю задовольняють згадані Протоколи, оскільки, зважаючи на недосконалість документа, їх можна доплюсувати до 1 \% лікарів, які Протоколами взагалі не користуються.

Характер нововведень, бажаних для практикуючих лікарів у цьому керівному документі представлений на рисунку 7. Так, 37 \% лікарів хочуть бачити у Протоколах біля кожного рекомендованого ними ЛП клас його доказовості, 25\% - новітні групи антибактеріальних засобів, 20 \% - поіменний перелік ЛП, а не лише загальну групову ̈̈х назву, 7 \% - діапазон цін як на оригінальні, так і на генеричні ЛП.

Оскільки анкетування було проведено упродовж 2015-2016 років - часу найгіршого забезпечення вакцинами в Україні від часів її створення, то оцінку стану забезпечення ними ЛПЗ лікарям було запропоновано дати за 2013 і 2014 роки. Як видно з рисунка 9, у нас наявна негативна тенденція забезпечення процесу вакцинопрофілактики, починаючи з 2013 p.

Висновок. Підсумовуючи результати проведеного анонімного опитування можна окреслити наступні шляхи подолання в Україні ДВІ:

Питання вакцинопрофілактики інфекційних хвороб, яким можна запобігти чи полегшити їх перебіг, повинно стати пріоритетом державної політики у сфері усієї системи охорони здоров'я населення України.

Для зменшення тягаря вакцинокерованих дитячих вірусних інфекцій (кору, краснухи) з боку дер- жави найперше необхідно забезпечити наявність вакцин в ЛПЗ, оскільки спеціалісти вкрай низько оцінюють поточний стан гарантування громадянам надання цього виду медичної допомоги, а представництво $\mathrm{OOH}$ констатувало, що наша держава має найнижчий рівень планової вакцинації у світі.

Необхідно створити позитивний імідж вакцинопрофілактики у суспільстві, схиляючи громадську думку на їі користь. Для цього доцільно обмежити кількість непрофесійних негативних меседжів у 3MI, в т.ч. Internet-просторі, а натомість розгорнути за участю фахівців широку інформаційну кампанію про необхідність імунопрофілактики та повсякчасну пропаганду ведення здорового способу життя серед усіх верств населення, а особливо - дітей та молоді.

Гарантувати поряд із наявністю, високу якість імунобіологічних препаратів, задіяних у процесі профілактики інфекційних хвороб. Відповідальність за безпечність та якість вакцин у процесі їх транспортування та зберігання покласти на фармацевтичну ланку системи охорони здоров'я.

Підняти авторитет лікаря та самооцінку його ролі у дискусії з батьками про необхідність щеплення дітей. Для цього необхідно запланувати та здійснити додаткове навчання спеціалістів (дитячих інфекціоністів, педіатрів, сімейних лікарів, провізорів, клінічних провізорів, психологів, соціальних працівників) з окресленого кола питань на курсах тематичного вдосконалення, передатестаційних циклах, стажуванні, в тому числі з використанням можливостей дистанційного навчання.

Розробити концепцію відповідальності паці-

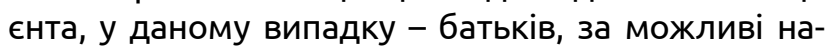
слідки їх відмови від проведення вакцинації дітей.

Для практичного виконання попередніх пунктів розробити та прийняти Державну програму протидії розповсюдженню дитячих інфекційних хвороб як стратегію єдиної державної політики щодо імунопрофілактики. У рамкахії реалізації затвердити нові Клінічні протоколи діагностики та лікування інфекційних хвороб у дітей, які 6 базувались на даних доказової медицини та фармакоекономіки.

Однак усі перелічені пункти не вдасться реалізувати без підняття загального рівня добробуту як медичних працівників, так і усіх громадян України загалом.

Перспективи подальших досліджень. Продовжити вивчення думок спеціалістів з питань протидії розповсюдженню ДВІ в Україні, а також провести анкетування інших зацікавлених сторін процесу вакцинопрофілактики - батьків дітей та провізорів, що і стане метою нашої подальшої роботи. 
Огляди літератури, оригінальні дослідження, погляд на проблему

ЛІТЕРАТУРА

1. На Прикарпатті зростає кількість хворих на кір: 12.12.2016 р. [Електронний ресурс]. - Режим доступу : http://www.newsru.ua/ukraine/12dec2016/prikarkor.

2. Посли США та Канади закликають до відновлення рутинної імунізації в Україні [Електронний ресурс]. Режим доступу : http://www.un.org.ua/ua/informatsiinyitsentr/news/3957-posly-ssha-ta-kanady-zaklykaiut-dovidnovlennia-rutynnoi-imunizatsii-v-ukraini

3. Про затвердження Плану заходів Міністерства охорони здоров'я України щодо удосконалення системи управління програмою імунізації за результатами рекомендацій Місії ВООЗ: Наказ МОЗ України від 15.11.2012 р. № 916 [Електронний ресурс]. - Режим доступу: http://www.apteka.ua/article/228823.

4. Про затвердження Протоколів діагностики та лікування інфекційних хвороб у дітей : Наказ МОЗ України від 09.07.2004 № 354 [Електронний ресурс].
- Режим доступу : http://www.moz.gov.ua/ua/portal/ dn_20040709_354.html.

5. Про порядок проведення профілактичних щеплень в Україні та контроль якості й обігу медичних імунобіологічних препаратів: Наказ МОЗ України від 16.09.2011 р. № 595 [Електронний ресурс] - Режим доступу: http://zakon4.rada.gov.ua/laws/show/z1159-11.

6. Супрун: Україні загрожує епідемія кору: 13.11.2016 р. [Електронний ресурс]. - Режим доступу : https://www.ukrinform.ua/rubric-society/2119680suprun-ukraini-zagrozue-epidemia-koru.html.

7. Федяк І. О. Дослідження динаміки фінансування програм імунопрофілактики в Україні [Текст] / І. О. Федяк, І. І. Іванюлик // Фармацевтичний часопис. № 1. - 2015. - С. 90-97.

8. Чумаченко Т. О. Вплив вакцинопрофілактики кору на епідемічну ситуацію в світі та Україні [Текст] / Т. О. Чумаченко, М. А. Емец//Профілактична медицина. - 2013. - № 1-2. (20). - C. 30-34.

\title{
JUSTIFICATION OF OVERCOMING WAYS OF CHILDREN'S VIRAL INFECTIONS IN UKRAINE
}

\author{
@I. O. Fedyak ', I. I. Ivanyulyk', , H. B. Mateyko', T. V. Tomashivska², L. M. Brovinska³, \\ T. M. Kaminska ${ }^{4}$, H. S. Rozhnova \\ Ivano-Frankivsk National Medical University' \\ Ternopil City Municipal Children's Hospital² \\ Vinnytsia Regional Children's Clinical Hospital of Infectious Diseases ${ }^{3}$ \\ Kyev City Children's Hospital of Infectious Diseases ${ }^{4}$ \\ Kharkiv Regional Children's Hospital of Infectious Diseases ${ }^{5}$
}

SUMMARY. The article presents the results of the survey of physicians (pediatric infectious disease specialists and pediatricians) on combating the spread in Ukraine, vaccine managed children's viral infections. Experts identified the main image and financial problems of the process of vaccination, assessed the current state of the pharmaceutical supply and proposed options to overcome these diseases. So, according to doctors opinion, their wide dissemination in Ukraine, accept the lack of vaccines, specified parents refusal of vaccination (40\%) and the formation of the mass media negative opinions about the benefits of immunization (35\%). Requires raise the self-esteem of the doctor's role in forcing parents in favor of vaccination, and the role of pharmacists - ensuring the quality and availability of vaccines. The problem of availability and timeliness of evidence-based information on prevention, treatment, and opposition of the spread of children's viral infections remains, as $58 \%$ of professionals believe that their necessiy for information implemented partially.

KEY WORDS: children's viral infections, vaccination, questioning.

Отримано 07.07.2016 